\title{
Aphid vectors of Papaya ringspot virus and their weed hosts in orchards in the major papaya producing and exporting region of Brazil
}

\author{
David dos Santos Martins a, José Aires Ventura a, *, Rita de Cássia A.L. Paula ${ }^{\text {b, }}$ \\ Maurício José Fornazier a , Jorge A.M. Rezende ${ }^{c}$, Mark P. Culik a , Paulo S.Fiuza Ferreira ${ }^{\text {d }}$,

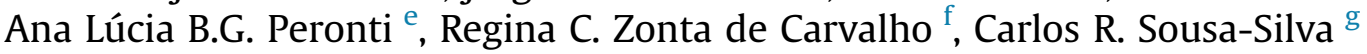 \\ a Instituto Capixaba de Pesquisa, Assistência Técnica e Extensão Rural (Incaper), PO Box 01146, 29052-970, Vitória, ES, Brazil \\ ${ }^{\mathrm{b}}$ Universidade Estadual do Sudoeste da Bahia, Campus de Vitória da Conquista, Departamento de Fitotecnia e Zootecnia, 45083-900, Vitória da Conquista, \\ BA, Brazil \\ ${ }^{\mathrm{c}}$ Escola Superior de Agricultura Luiz de Queiroz/Universidade de São Paulo, Departamento de Fitopatologia e Nematologia, 13418-900, Piracicaba, SP, Brazil \\ d Universidade Federal de Viçosa, Departamento de Entomologia, 36570-900, Viçosa, MG, Brazil \\ e Universidade Estadual Paulista Júlio de Mesquita Filho, Faculdade de Ciências Agrárias e Veterinárias de Jaboticabal, Departamento de Fitossanidade, \\ 14884-900, Jaboticabal, SP, Brazil \\ ${ }^{\mathrm{f}}$ Centro de Diagnóstico Marcos Enrietti, 80040-340, Curitiba, PR, Brazil \\ ${ }^{\mathrm{g}}$ Universidade Federal de São Carlos, Departamento de Ecologia e Biologia Evolutiva, 13565-905, São Carlos, SP, Brazil
}

\section{A R T I C L E I N F O}

\section{Article history:}

Received 6 February 2016

Received in revised form

25 August 2016

Accepted 28 August 2016

\section{Keywords:}

Carica papaya

Epidemiology

Management tactics

Potyvirus

Virus transmission

Weed hosts

\begin{abstract}
A B S T R A C T
Papaya ringspot, one of the most important diseases of papaya, is caused by Papaya ringspot virus type $\mathrm{P}$ (PRSV-P), which is transmitted by various aphid species. Objectives of this research were to identify the aphid species and their weed hosts of papaya orchards in the major papaya producing and exporting region of Brazil in northern Espírito Santo State. Aphids were collected from weed hosts, and with Möericke-type traps in papaya orchards of twenty farms in Linhares, Sooretama and Aracruz municipalities of Espírito Santo, Brazil. A total of forty aphid species were collected, of which 22 are new records in the State. Thirty-eight aphid species were identified from traps, including Aphis craccivora Koch, A. gossypii Glover, A. spiraecola Patch, Myzus persicae (Sulzer), and Toxoptera citricidus (Kirkaldy), known vectors of PRSV-P. Cryptomyzus Oestlund (Aphididae) is recorded for the first time in Brazil. Thirteen aphid species associated with 22 weed species of 14 families were collected. Aphis gossypii, which has been reported to be one of the most efficient vectors of PRSV-P, infested the greatest number of weed hosts. Chamaesyce hyssopifolia (L.) Small, Euphorbia hirta L. (Euphorbiaceae), Commelina benghalensis L. (Commelinaceae), Lepidium virginicum L. (Brassicaceae) and Sida sp. (Malvaceae) were the most frequently infested weeds. Commelina benghalensis was infested by the greatest number of aphid species during this study. Integrated management of weed hosts of aphids to reduce aphid populations in papaya orchards may be useful for control of PRSV-P. Based on accurate knowledge of the aphid and weed species present in papaya orchards obtained in this study, integrated pest management efforts may be more efficiently directed toward eliminating the most frequently infested weed species that serve as hosts for aphid vectors of PRSV-P.
\end{abstract}

๑) 2016 Elsevier Ltd. All rights reserved.

\section{Introduction}

Papaya ringspot, caused by Papaya ringspot virus type P (PRSV$\mathrm{P})$, genus Potyvirus (Potyviridae) is one of the major diseases that limits papaya production in most countries (Fermin et al., 2010).

\footnotetext{
* Corresponding author.

E-mail address: ventura@incaper.es.gov.br (J.A. Ventura).
}

The loss of production may reach $100 \%$ depending on the level of incidence of the disease and age of infected plants (Singh et al., 2005; Martins and Ventura, 2007; Tennant et al., 2007; Tripathi et al., 2008). Diseased papaya trees exhibit symptoms of mosaic, foliar deformation, oily ringspots on the fruits, and oily spots or streaks on the leaf petioles. Plants may appear stunted, and infected seedlings present distinct leaf vein-clearing with the youngest leaves curving downwards in 1-2 weeks after infection; after several weeks, the leaves become mottled and distorted, with lobes 
greatly deformed (Purcifull et al., 1984; Lima et al., 2001). Infected young plants may not be killed by this virus, and may produce fruits, and they become important reservoirs of inoculum (Ventura et al., 2004; Costa, 2005). Dissemination of PRSV-P in papaya orchards is very rapid, particularly in regions with high population of aphids. From the first foci, all plants in an orchard may be infected within a period of 4-7 months. Thus, infected plants must be immediately removed (roguing) after the first appearance of disease symptoms to prevent further spread of the virus to adjacent plants or nearby orchards (Ventura et al., 2004).

Aphids (Hemiptera: Aphidoidea) are vectors of PRSV-P, and their rapid life cycle, high reproductive rate, and dispersal ability make these insects suitable for rapid dissemination of this virus (Costa, 2005; Fereres and Moreno, 2009). Twenty-one species of aphids have been confirmed as vectors of PRSV-P in a non-persistent virusvector relationship (Purcifull et al., 1984; Gonsalves, 1998; Culik et al., 2003). Aphid species that have been reported to transmit PRSV-P include Acyrthosiphon malvae (Mosley), Aphis craccivora Koch, A. fabae Scopoli, A. coreopsidis Thomas, A. gossypii Glover, A. medicaginis Koch, A. nerii Boyer de Fonscolombe, A. rumicis Linnaeus, A. spiraecola Patch, Uroleucon sonchi (Linnaeus), Myzus persicae (Sulzer), Pentalonia nigronervosa Coquerel, Rhopalosiphum maidis (Fitch), Toxoptera aurantii (Boyer de Fonscolombe), and T. citricidus (Kirkaldy) (Jensen, 1949; Capoor and Varma, 1958; Lana, 1980; Namba and Higa, 1981; Wang, 1981; Vegas et al., 1985; Prasad and Sarkar, 1989; Culik et al., 2003; Kalleshwaraswamy et al., 2007). Aphis coreopsidis, A. fabae, A. gossypii, M. persicae, and T. citricidus have been confirmed as vectors of PRSP-P in Brazil (Martins et al., 2009).

Aphids do not colonize papaya trees, but the virus is acquired and transmitted by aphids during brief periods of feeding probes to locate suitable hosts for colonization (Kalleshwaraswamy et al., 2007), and Fermin et al. (2010) proposed that it is necessary to evaluate the different aphid species that are able to transmit PRSV$P$ to develop effective management methods for the most abundant and prevalent species. The efficiency of PRSV-P transmission by aphids depends on the aphid species and viral isolate (Adsuar, 1947; Jensen, 1949; Capoor and Varma, 1958; Lana, 1980). Many aphid species and their host plants are exotic in the tropics, and these insects are commonly associated with herbaceous plant hosts (Dixon, 1987; Peronti et al., 2002). Most commercial papaya orchards in the Brazilian producing and exporting region are maintained with spontaneous vegetation (weeds) among the rows of papaya trees, based on requirements for plant groundcover of GlobalGap and Brazilian Integrated Papaya Production (Martins et al., 2009; Mansilla et al., 2013). Therefore, because little is known of the aphid species and their weed hosts that may be present in papaya orchards in Brazil, the objectives of this study were to identify the aphid species and their host plants in commercial papaya orchards to improve understanding of their importance in the epidemiology of papaya ringspot for development of integrated pest management (IPM) strategies.

\section{Materials and methods}

Aphids species were sampled during two years in twenty papaya producing farms with a total of 333 ha cropped with 'Golden', 'Sunrise Solo' and 'Tainung 01' cultivars. Fifteen farms were sampled in Linhares $\left(19^{\circ} 22^{\prime} 55,8^{\prime \prime} \mathrm{S} ; 40^{\circ} 01^{\prime} 43,2^{\prime \prime} \mathrm{W}\right)$, three in Sooretama ( $\left.19^{\circ} 04^{\prime} 18,0^{\prime \prime} \mathrm{S} ; 40^{\circ} 08^{\prime} 52,0^{\prime \prime} \mathrm{W}\right)$, and two in Aracruz (19 $46^{\prime} 04,7^{\prime \prime}$ S; $\left.40^{\circ} 10^{\prime} 34,8^{\prime \prime} \mathrm{W}\right)$ municipalities, located in northern Espírito Santo State, the main papaya producing and exporting region of Brazil (Fig. 1).

Aphids were collected in papaya orchards with Möericke-type yellow traps (Oliveira et al., 1977) mounted on wood stands $0.50 \mathrm{~m}$ above the ground, at a rate of one trap per hectare, with a maximum of 10 traps per orchard. Traps were placed in the orchards for $48 \mathrm{~h}$, at weekly intervals for two years. All winged aphids specimens collected were fixed in $100 \%$ ethyl alcohol. Aphids were also collected from infested weeds of five $1 \mathrm{~m}^{2}$ plots, randomly located between the rows of papaya trees of each orchard as follows: the number of weed plants in the plots was recorded and aphid infested weeds found in the plots were removed with their roots, placed in kraft paper bags and transported to the Laboratory of Entomology of the Instituto Capixaba de Pesquisa, Assistência Técnica e Extensão Rural (Incaper) where they were potted and the number of aphids specimens counted. Subsequently, the infested plants were transferred to screened cages in climate control chambers with temperature $25 \pm 2{ }^{\circ} \mathrm{C}$, relative humidity $70 \pm 10 \%$, and L:D 14:10 to obtain winged forms of the aphids. Winged aphid specimens that developed on the weed samples were collected with forceps and fixed in $100 \%$ ethyl alcohol for identification.

Aphids were identified by the authors (A.L.B.G. Peronti and R.C.Z. Carvalho) and Dr. Susan Halbert, Florida Department of Agriculture, USA. Weed hosts were preserved and identified at Incaper with nomenclature based on Tropicos.org - Missouri Botanical Garden (Tropicos, 2013). Voucher specimens are deposited in the arthropod collection of the Instituto Capixaba de Pesquisa, Assistência Técnica e Extensão Rural (Incaper), Vitória, Espírito Santo, Brazil, and in the entomological collection of the Department of Entomology, Universidade Federal de Viçosa (UFV).

\section{Results}

A total of 356 samples with aphids were obtained from traps, including 3874 aphid specimens belonging to 38 species of six families (Table 1). Aphis spiraecola, A. gossypii, T. citricidus, and A. craccivora were the most frequent and constant species found in the papaya orchards (each in more than $20 \%$ of the samples and making up from 5.1 to $52.0 \%$ of the total number of aphids collected). Of the 38 aphid species collected from traps, 21 were recorded for the first time in Espírito Santo (Table 1).

A total of 42 weed species from 16 families were identified in the papaya orchards, and 22 of these weed species (55\%) in 21 genera of 14 families were identified as aphid hosts (Table 2). These aphid host plants represented $9.4 \%$ of the total number of weed plants growing among the rows of papaya trees. Aphididae was the only family of the 13 aphid species found on the weed hosts. Aphis gossypii was the most frequent species, found in 55\% of samples, and colonized 14 weed host species (Table 2). A. solanella Theobald found on Solanum americanum Mill. (Solanaceae), and Cryptomyzus sp. found on Commelina benghalensis L. (Commelinaceae), and on Leonotis nepetaefolia (L.) R. $\mathrm{Br}$ (Labiatae) were not collected in traps. The genus Cryptomyzus Oestlund (Aphididae) was recorded for the first time in Brazil. The most frequent weed hosts of aphid species in papaya orchards were Commelina benghalensis (Commelinaceae), Sida sp. (Malvaceae), Chamaesyce hyssopifolia (L.) Small, Euphorbia hirta L. (Euphorbiaceae) and Lepidium virginicum L. (Brassicaceae). Cucumis anguria L. was the only species of Cucurbitaceae found as an aphid host in this study.

\section{Discussion}

Results of this research indicate that a high diversity of aphids is present in papaya orchards in northern Espírito Santo, including at least 40 species, of which 22 were recorded for the first time in this State. Of the 40 species found in papaya orchards in this study, Aphis coreopsidis, A. gossypii, M. persicae and T. citricidus have been reported to be efficient vectors of PRSV-P (Martins and Ventura, 2007). Aphis craccivora, A. nerii, A. spiraecola, L. erysimi, 


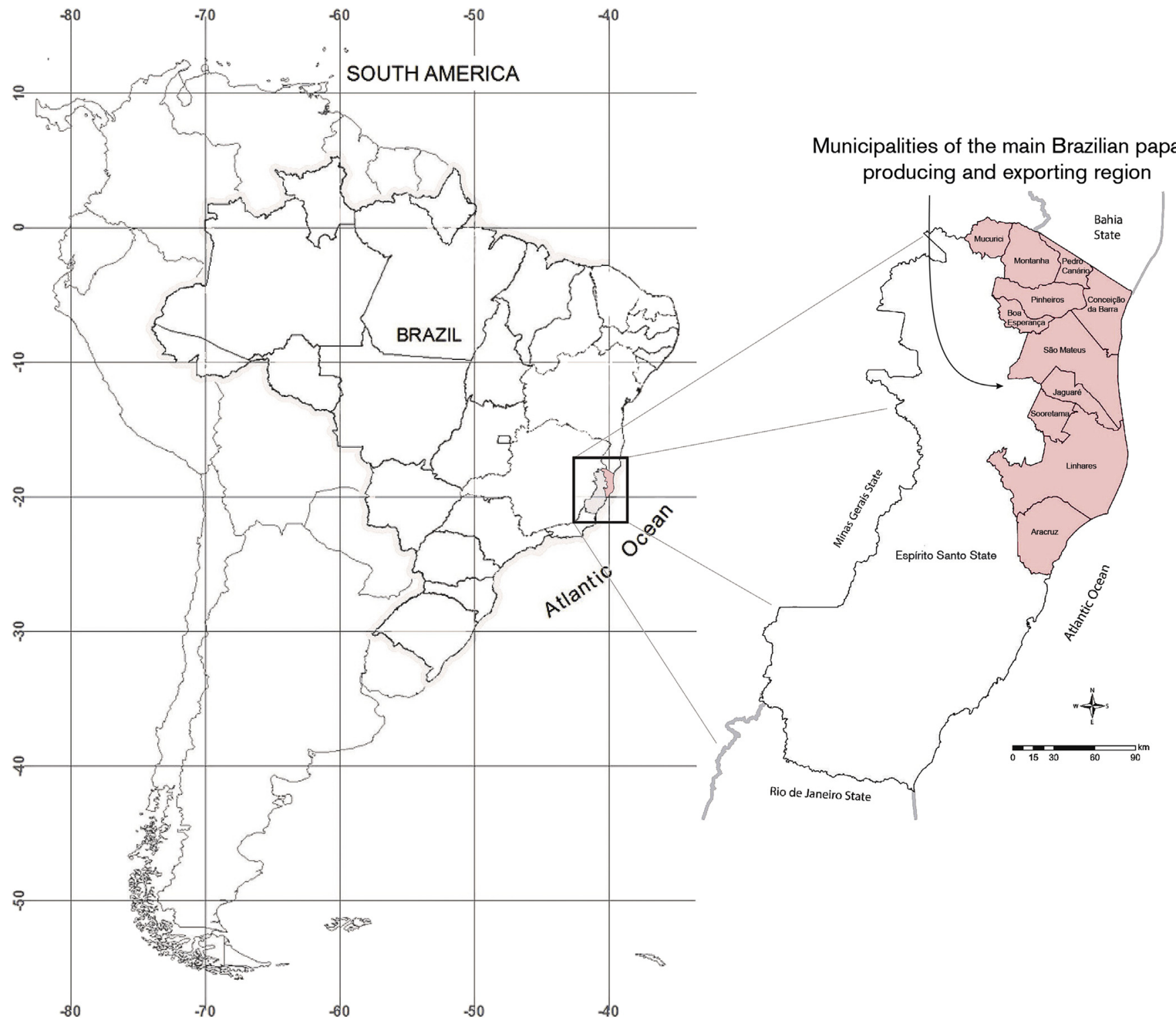

Fig. 1. Location of the research area in the main papaya producing-exporting region of Brazil in the State of Espírito Santo.

P. nigronervosa, R. maidis, T. aurantii, U. ambrosiae (Thomas), and $U$. sonchi were also collected in this study, and are vectors of PRSV-P (Jensen, 1949; Capoor and Varma, 1958; Higa and Namba, 1971; Lana, 1980; Culik et al., 2003). At least 16 species of aphids have previously been reported in this region, and A. gossypii, A. spiraecola, L. erysimi (Kaltenbach), M. persicae, T. citricidus and U. sonchi (L.) have been considered to be the most common aphid species in this region (Oliveira et al., 1977; Souza-Silva and Ilharco, 1995).

The PRSV-P transmission efficiency by aphids has been studied in papaya-production regions worldwide, and A. gossypii M. persicae, and $A$. rumicis Linnaeus, were the most efficient vectors; Acyrthosiphon malvae, A. medicaginis Koch, Macrosiphum euphorbiae (Thomas), Micromyzus formosanus (Takahashi), R. maidis (Fitch), T. aurantii, T. citricidus, and $U$. sonchi also transmitted PRSV-P (Jensen, 1949; Capoor and Varma, 1958; Vegas et al., 1985; Kalleshwaraswamy et al., 2007).

The most frequent and constant aphid species (number of individuals of species/total, and number of samples with species/total; Table 1) found in this study, A. spiraecola, A. gossypii, T. citricidus, and A. craccivora, are polyphagous species, abundant in anthropogenic environments, and are considered to be pests in many crops (Leal and Oliveira, 1983; Lazzarotto and Lazzari, 1998; Peronti et al., 2002). The three most frequent species found in papaya orchards in this study, A. spiraecola, A. gossypii, and T. citricidus, are also considered to be efficient vectors of PRSV-P (Adsuar, 1947; Jensen, 1949; Videla, 1953; Capoor and Varma, 1958; Higa and Namba, 1971; Lana, 1980; Kalleshwaraswamy and Krishna Kumar, 2008), and their presence in papaya orchards represents a serious problem for the production of papaya in Brazil (A. craccivora has been shown to be an inefficient vector of PRSV-P) (Lana, 1980; Ventura et al., 2004).

Information on the diversity of aphids and their weed hosts in papaya orchards is useful for understanding the epidemiology of papaya ringspot, and for the development of integrated management strategies for this disease. The most frequent weed and host of the highest number of aphid species in papaya orchards, $C$. benghalensis is a very common and widely distributed pest. This weed species occurs throughout the year in this papaya region, and 
Table 1

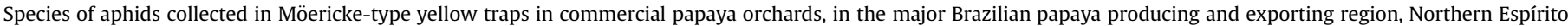
Santo State.

\begin{tabular}{|c|c|c|c|c|c|}
\hline Species & Municipality $^{\mathrm{b}}$ & No. of samples with the species ${ }^{c}$ & Constancy $(\%)^{\mathrm{d}}$ & No. of specimens & Frequency $(\%)^{e}$ \\
\hline \multicolumn{6}{|l|}{ Aphididae } \\
\hline Aphis coreopsidis (Thomas, 1878) & A, L, S & 25 & 7.02 & 52 & 1.34 \\
\hline Aphis craccivora Koch, $1854^{\mathrm{f}}$ & A, L, S & 81 & 22.75 & 198 & 5.11 \\
\hline Aphis cf. fabae Scopoli, 1763 & A, L, S & 27 & 7.58 & 167 & 4.31 \\
\hline Aphis gossypii Glover, $1877^{\mathrm{g}}$ & $A, L, S$ & 159 & 44.66 & 453 & 11.69 \\
\hline Aphis nerii Boyer de Fonscolombe, $184^{\mathrm{f}}$ & $A, L, S$ & 35 & 9.83 & 69 & 1.78 \\
\hline Aphis spiraecola Patch, $1914^{\mathrm{f}}$ & $A, L, S$ & 260 & 73.03 & 2015 & 52.01 \\
\hline Brachycaudus helichrysi (Kaltenbach, 1843) & $A, L, S$ & 8 & 2.25 & 9 & 0.23 \\
\hline Capitophorus hippophaes (Walker, 1852) ${ }^{\mathrm{a}}$ & $A, L, S$ & 10 & 2.81 & 12 & 0.31 \\
\hline Carolinaia caricis Wilson, $1911^{\mathrm{a}}$ & S & 1 & 0.28 & 1 & 0.03 \\
\hline Hyperomyzus lactucae (Linnaeus, 1758) ${ }^{\mathrm{f}}$ & $\mathrm{S}$ & 1 & 0.28 & 1 & 0.03 \\
\hline Hysteroneura setariae (Thomas, 1878) & $\mathrm{L}, \mathrm{S}$ & 10 & 2.81 & 12 & 0.31 \\
\hline Lipaphis erysimi (Kaltenbach, 1843) f $^{\mathrm{f}}$ & $A, L, S$ & 30 & 8.43 & 76 & 1.96 \\
\hline Longiunguis sacchari (Zehntner, 1897) & $\mathrm{L}, \mathrm{S}$ & 11 & 3.09 & 20 & 0.52 \\
\hline Microparsus vignaphilus (Blanchard, 1922) & $\mathrm{L}, \mathrm{S}$ & 2 & 0.56 & 3 & 0.08 \\
\hline Myzus persicae (Sulzer, 1776$)^{g}$ & A, L, S & 11 & 3.09 & 12 & 0.31 \\
\hline Pentalonia nigronervosa Coquerel, $1859^{\mathrm{a}, \mathrm{f}}$ & $A, L, S$ & 13 & 3.65 & 17 & 0.44 \\
\hline Protaphis terricola (Rondani, 1847) & $\mathrm{L}, \mathrm{S}$ & 37 & 10.39 & 55 & 1.42 \\
\hline Rhopalosiphum maidis (Fitch, 1856) & A, L, S & 25 & 7.02 & 27 & 0.70 \\
\hline Rhopalosiphum nymphaeae (Linnaeus, 1761) ${ }^{\mathrm{a}}$ & $\mathrm{L}$ & 1 & 0.28 & 1 & 0.03 \\
\hline Rhopalosiphum padi (Linnaeus, 1758) ${ }^{\mathrm{a}}$ & $\mathrm{L}, \mathrm{S}$ & 2 & 0.56 & 2 & 0.05 \\
\hline Rhopalosiphum rufiabdominale (Sasaki, 1899) & $\mathrm{L}, \mathrm{S}$ & 5 & 1.40 & 5 & 0.13 \\
\hline Schizaphis graminum (Rondani, 1852) & $\mathrm{L}, \mathrm{S}$ & 15 & 4.21 & 27 & 0.70 \\
\hline Tetraneura nigriabdominalis (Sasaki, 1899) ${ }^{\mathrm{a}}$ & $A, L, S$ & 26 & 7.30 & 43 & 1.11 \\
\hline Toxoptera aurantii (Boyer de Fonscolombe, 1841) ${ }^{\mathrm{f}}$ & A, L, S & 51 & 14.33 & 82 & 2.12 \\
\hline Toxoptera citricidus (Kirkaldy, 1907) ${ }^{g}$ & $A, L, S$ & 96 & 26.97 & 390 & 10.07 \\
\hline Uroleucon ambrosiae (Thomas, 1878) & A, L, S & 13 & 3.65 & 15 & 0.39 \\
\hline Uroleucon compositae (Theobald, 1915) ${ }^{\mathrm{a}}$ & A, L, S & 35 & 9.83 & 64 & 1.65 \\
\hline Uroleucon sonchi (Linnaeus, 1767) ${ }^{\mathrm{f}}$ & A, S & 3 & 0.84 & 3 & 0.08 \\
\hline \multicolumn{6}{|l|}{ Drepanosiphidae } \\
\hline Anoecia cornicola (Walsh, 1863) ${ }^{\mathrm{a}}$ & $\mathrm{S}$ & 1 & 0.28 & 1 & 0.03 \\
\hline Lizerius cermelii Quednau, $1974^{a}$ & $\mathrm{~L}$ & 1 & 0.28 & 1 & 0.03 \\
\hline Lizerius tuberculatus (Blanchard, 1939) ${ }^{\mathrm{a}}$ & $\mathrm{S}$ & 1 & 0.28 & 1 & 0.03 \\
\hline Sipha flava (Forbes, 1885) & $\mathrm{L}$ & 2 & 0.56 & 2 & 0.05 \\
\hline Greenideidae & & & & & 0.00 \\
\hline Brasilaphis bondari Mordvilko, $1930^{\mathrm{a}}$ & $\mathrm{S}$ & 1 & 0.28 & 1 & 0.03 \\
\hline \multicolumn{6}{|l|}{ Hormaphididae } \\
\hline Cerataphis brasiliensis (Hempel, 1901) & $A, L, S$ & 9 & 2.53 & 9 & 0.23 \\
\hline Cerataphis orchidearum (Westwood, 1879) & $\mathrm{L}, \mathrm{S}$ & 11 & 3.09 & 11 & 0.28 \\
\hline \multicolumn{6}{|l|}{ Lachnidae } \\
\hline Cinara atlantica (Wilson, 1919) ${ }^{\mathrm{a}}$ & $\mathrm{L}$ & 1 & 0.28 & 1 & 0.03 \\
\hline Cinara fresai (Blanchard, 1939) & $\mathrm{S}$ & 1 & 0.28 & 2 & 0.05 \\
\hline \multicolumn{6}{|l|}{ Pemphigidae } \\
\hline Geopemphigus floccosus (Moreira, 1925) & $\mathrm{L}, \mathrm{S}$ & 14 & 3.93 & 14 & 0.36 \\
\hline
\end{tabular}

${ }^{a}$ First record of species in the State of Espírito Santo, Brazil.

b Occurrence: Aracruz (A), Linhares (L), Sooretama (S).

c Number of samples with the species present in relation to the total collected.

d Presence of the species in the total samples.

e Number of individuals of each species in relation to the total specimens collected.

f Species confirmed as vectors of PRSV-P (Jensen, 1949; Capoor and Varma, 1958; Namba and Higa, 1981; Lana, 1980; Wang, 1981; Vegas et al., 1985; Prasad and Sarkar, 1989; Culik et al., 2003).

g Species confirmed as vectors of PRSV-P in Brazil (Martins et al., 2009).

this study demonstrates that it is one of the most important natural reservoirs of aphid vectors of PRSV-P. Aphid species found on this weed species include A. gossypii, a vector of PRSV-P in Brazil, and considered one of the most efficient PRSV vectors worldwide (Rezende and Martins, 2005). Tetraneura nigriabdominalis, and $U$. ambrosiae were also found on this weed, however their transmission efficiency of PRSV-P is not known. Blainvillea rhomboidea Cass. is a host of $A$. spiraecola, thus it may be considered another important weed in PRSV-P disease management in papaya orchards because this aphid species is a relatively efficient for transmission of PRSV-P (Adsuar, 1947; Videla, 1953). Such weed hosts of aphids may be eradicated as a strategy for disease management (Martins et al., 2009; Ventura et al., 2004). Cucumis anguria is a common weed in Brazilian crops, particularly in papaya orchards, and it has not been related with natural infection of PRSV-P; however, other cucurbits such as Momordica charantia L., and Cucurbita maxima Duchesne cV. Exposição (pumpkin) were not infected by PRSV-P though mechanical or aphid inoculations, and field exposure of plants (Spadotti et al., 2013; Mansilla et al., 2013). These data indicate that these cucurbits species do not seem to have a role in the epidemiology of the papaya ringspot in Brazil. However, these plant species may be reservoirs of aphid populations.

Several strategies have been adopted to reduce the incidence of PRSV-P such as the use of certified seedlings, planting in virus free areas whenever available, avoiding intercropping with Cucurbitaceae, systematic roguing of infected papaya trees, use of resistant varieties, cross protection (Rezende and Müller, 1995; Lima et al., 2001; Rezende and Martins, 2005), and use of resistant transgenic plants (Gonsalves, 1998; Lima et al., 2001). The commercial Brazilian papaya varieties are not resistant to PRSV-P (Singh et al., 
Table 2

Species of aphids colonizing weeds in commercial papaya orchards in the major Brazilian papaya producing and exporting region, Northern Espírito Santo State.

\begin{tabular}{|c|c|c|c|c|}
\hline \multirow[t]{2}{*}{ Aphid Species } & \multicolumn{2}{|c|}{ Samples } & \multirow[t]{2}{*}{ Botanical family } & \multirow[t]{2}{*}{ Host plant } \\
\hline & No & Frequency (\%) & & \\
\hline Aphis coreopsidis (Thomas, 1878) & 5 & 6.58 & $\begin{array}{l}\text { Asteraceae } \\
\text { Asteraceae }\end{array}$ & $\begin{array}{l}\text { Bidens pilosa } \mathrm{L} . \\
\text { Emilia coccinea (Sims) G. Don }\end{array}$ \\
\hline Aphis craccivora Koch, 1854 & 6 & 7.89 & $\begin{array}{l}\text { Amaranthaceae } \\
\text { Euphorbiaceae }\end{array}$ & $\begin{array}{l}\text { Amaranthus deflexus L. } \\
\text { Chamaesyce hyssopifolia (L.) Small }\end{array}$ \\
\hline Aphis gossypii Glover, 1877 & 42 & 55.26 & $\begin{array}{l}\text { Loranthaceae } \\
\text { Malvaceae } \\
\text { Malvaceae } \\
\text { Commelinaceae } \\
\text { Lamiaceae } \\
\text { Asteraceae } \\
\text { Asteraceae } \\
\text { Portulacaceae } \\
\text { Convolvulaceae } \\
\text { Cucurbitaceae } \\
\text { Asteraceae } \\
\text { Asteraceae } \\
\text { Euphorbiaceae } \\
\text { Asteraceae }\end{array}$ & $\begin{array}{l}\text { Psiittacanthus cordatus (Hoff.) Blume } \\
\text { Sida cordifolia L. } \\
\text { Sida sp. } \\
\text { Commelina benghalensis L. } \\
\text { Leonotis nepetaefolia (L.) R. Br. } \\
\text { Siegesbeckia orientalis L. } \\
\text { Agerantum conyzoides L. } \\
\text { Portulaca oleracea L. } \\
\text { Ipomoea ramosissima (Poir.) Choisy } \\
\text { Cucumis anguria L. } \\
\text { Bidens pilosa L. } \\
\text { Gnaphalium spicatum Mill. } \\
\text { Euphorbia hirta L. } \\
\text { Emilia coccinea (Sims) G. Don }\end{array}$ \\
\hline Aphis nerii Boyer de Fonscolombe, 1841 & 2 & 2.63 & Euphorbiaceae & Chamaesyce hyrta (L.) Millsp. \\
\hline Aphis solanella Theobald, 1914 & 4 & 5.26 & Solanaceae & Solanum americanum Mill. \\
\hline Aphis sp. & 2 & 2.63 & $\begin{array}{l}\text { Asteraceae } \\
\text { Commelinaceae }\end{array}$ & $\begin{array}{l}\text { Ageratum conyzoides } \mathrm{L} . \\
\text { Commelina benghalensis } \mathrm{L} \text {. }\end{array}$ \\
\hline Aphis spiraecola Patch, 1914 & 2 & 2.63 & Asteraceae & Blainvillea rhomboidea Cass. \\
\hline Brachycaudus helichrysi (Kaltenbach, 1843) & 2 & 2.63 & Asteraceae & Ageratum conyzoides L. \\
\hline Cryptomyzus sp. ${ }^{\text {a }}$ & 4 & 5.26 & $\begin{array}{l}\text { Labiatae } \\
\text { Commelinaceae }\end{array}$ & $\begin{array}{l}\text { Leonotis nepetaefolia (L.) R. Br } \\
\text { Commelina benghalensis L. }\end{array}$ \\
\hline Lipaphis erysimi (Kaltenbach, 1843) & 1 & 1.32 & Brassicaceae & Lepidium virginicum $\mathrm{L}$. \\
\hline Tetraneura nigriabdominalis (Sasaki, 1899) & 1 & 1.32 & Commelinaceae & Commelina benghalensis L. \\
\hline Uroleucon ambrosiae (Thomas, 1878) & 3 & 3.95 & $\begin{array}{l}\text { Asteraceae } \\
\text { Commelinaceae } \\
\text { Boraginaceae }\end{array}$ & $\begin{array}{l}\text { Acanthospermum autrale (Loef.) } \\
\text { Commelina benghalensis L. } \\
\text { Echium sp. }\end{array}$ \\
\hline Uroleucon compositae (Theobald, 1915) & 2 & 2.63 & Malvaceae & Hibiscus sp. \\
\hline Total & 76 & 100.00 & & \\
\hline
\end{tabular}

a First record of this genus in Brazil.

2005), and none of them are transgenic (Costa et al., 2013). Cucurbitaceae crops such as squash intercropped or in the vicinity of papaya orchards should be avoided because cucurbits are susceptible to PRSV-P (Mansilla et al., 2013). The use of live barriers, such as sugarcane and intercropping of corn or sorghum may also be used to inhibit the migration of aphids into papaya orchards (Paéz-Redondo, 2003). However, spontaneous vegetation that is maintained among the rows of papaya trees, based on groundcover requirements of international standards for production and export of Brazilian papaya, such as GlobalGap and Brazilian Integrated Fruit Production, may be one of the major problems for the integrated management of aphids to prevent the spread of PRSV-P. Weed hosts that serve as hosts of vectors such as A. gossypii could be eradicated, and replaced with aphid non-host plants that also protect the soil. Information generated in this research may be used to contribute to a management plan for papaya ringspot disease including management of groundcover of papaya orchards to eliminate weeds, such as $C$. benghalensis, that are major hosts of aphid vectors.

Thus, strategies for the management of aphid weed hosts in papaya orchards should be incorporated into the integrated pest management tactics in papaya orchards. This will prevent the multiplication and the dispersion of PRSV-P vectors, and may contribute to the reduction in the spread of the virus and reduce the percentage of eradicated papaya trees in mandatory operations of systematic roguing of virus infected plants.

\section{Acknowledgements}

We thank the Fundação de Amparo à Pesquisa e Inovação do
Espírito Santo (FAPES, grant no: 53236092/11), Conselho Nacional de Desenvolvimento Científico e Tecnológico (CNPq, grant no: 307752/2012-7), and Banco do Nordeste do Brasil (BNB) for financial support; and many thanks to Susan Halbert, Florida Department of Agriculture (USA), for identification of aphid species.

\section{References}

Adsuar, J., 1947. Studies on virus diseases of papaya (Carica papaya) in Puerto Rico. II: transmission of papaya mosaic by the citrus aphid (Aphis spiraecola Patch). J. Agric. Univ. P. R. 31, 257-259.

Capoor, S.P., Varma, P.M., 1958. A mosaic disease of papaya in Bombay. Indian J. Agric. Sci. 28, 225-233.

Costa, A.F.S., Dantas, J.L.L., Pereira, M.G., Cattaneo, L.F., Costa, A.N., Moreira, S.O., 2013. Cultivo do mamoeiro: botânica, melhoramento e variedades. Inf. Agropecu. $34,14-24$.

Costa, C.L., 2005. As inter-relacões vírus-afídeos vetores e o controle da mancha anelar do mamoeiro causada pelo Papaya ringspot virus-P. In: Martins, D.S. (Ed.), Papaya Brasil: mercado e inovações tecnológicas para o mamão. Incaper, Vitória, Brasil, pp. 183-191.

Culik, M.P., Martins, D.S., Ventura, J.A., 2003. Índice de artrópodes pragas do mamoeiro (Carica papaya L.). Incaper, Vitória, Brasil. Documentos 121.

Dixon, A.F.G., 1987. The way of life of aphids: hosts specificity, speciation and distribution. In: Minks, A.K., Harrewijn, P. (Eds.), World Crop Pests: Aphids Their Biology, Natural Enemies and Control. Elsevier Science Publishers, Amsterdam, pp. $15-320$.

Fereres, A., Moreno, A., 2009. Behavioral aspects influencing plant virus transmission by homopteran insects. Virus Res. 141, 158-168.

Fermin, G.A., Castro, L.T., Tennant, P.F., 2010. CP-transgenic and non-transgenic approaches for the control of papaya ringspot: current, situation and challenges. Transgenic Plant J. 4,1-15.

Gonsalves, D., 1998. Control of Papaya ringspot virus: a case study. Annu. Rev. Phytopathol. 36, 415-437.

Higa, S.Y., Namba, R., 1971. Vectors of the papaya mosaic virus in Hawaii. Proc. Hawaii. Entomol. Soc. 21, 93-96.

Jensen, D.D., 1949. Papaya ringspot virus and its insect vector relationships. Phytopathology 39, 212-220. 
Kalleshwaraswamy, C.M., Krishnakumar, N.K., Verghese, A., Dinesh, M.R., Ranganath, H.R., Venugopalan, R., 2007. Role of transient aphid vectors on the temporal spread of papaya ringspot virus in south India. Acta Hort. 740, $251-258$.

Kalleshwaraswamy, C.M., Krishna Kumar, N.K., 2008. Transmission efficiency of Papaya ringspot virus by three aphid species. Phytopathology 98, 541-546.

Lana, A.F., 1980. Transmission and properties of viruses isolated from Carica papaya in Nigeria. J. Hortic. Sci. 55, 191-197.

Lazzarotto, C.M., Lazzari, S.M.N., 1998. Richness and diversity of aphids (Homoptera, Aphididae) along an altitudinal gradient in the Serra do Mar, Paraná, Brazil. Rev. Bras. Zool. 15, 977-983.

Leal, M.C., Oliveira, M.H., 1983. Estudo sistemático dos afídeos de praças públicas do Recife, PE. Bras. Florest. 56, 37-40.

Lima, R.C.A., Lima, J.A.A., Souza Jr., M.T., Pio-Ribeiro, G., Andrade, G.P., 2001. Etiologia e estratégias de controle de viroses do mamoeiro no Brasil. Fitopatol. Bras. 26, 689-702.

Mansilla, P.J., Moreira, A.G., Mello, A.P.O.A., Rezende, J.A.M., Ventura, J.A., Yuki, V.A., Levatti, F.J., 2013. Importance of cucurbits in the epidemiology of papaya ringspot virus - type P. Plant Pathol. 62, 571-577.

Martins, D.S., Ventura, J.A., 2007. Vetores de doenças do mamoeiro: monitoramento e controle. In: Martins, D.S., Costa, A.N., Costa, A.F.S. (Eds.), Papaya Brasil: manejo, qualidade e mercado do mamão. Incaper, Vitória, Brasil, pp. 113-128.

Martins, D.S., Ventura, J.A., Tatagiba, J.S., 2009. Produção integrada de mamão no Estado do Espírito Santo. In: Brasil. Ministério da Agricultura, Pecuária e Abastecimento (Ed.), Produção integrada no Brasil: agropecuária sustentável alimentos seguros. MAPA/ACS, Brasília, Brasil, pp. 569-626.

Namba, R., Higa, S.Y., 1981. Papaya mosaic transmission as affected by the duration of the acquisition probe of the green peach aphid - Myzus persicae (Sulzer). Proc. Hawaii. Entomol. Soc. 23, 431-443.

Oliveira, A.M., Pacova, B.E.V., Barcellos, D.F., Sudo, S., 1977. Afídeos alados coletados em armadilhas amarelas no estado do Espírito Santo (Homoptera: Aphidoidea). Pesqui. Agropecu. Bras. 12, 125-130.

Paéz-Redondo, A., 2003. Manejo del vírus de la mancha anular de la papaya en la región Caribe colombiana, vol. 8. CORPOICA: Boletín Técnico, Vaelledupar, Colombia.

Peronti, A.L.B.G., Sousa-Silva, C.R., Ilharco, F.A., 2002. First report of Melanaphis bambusae (Homoptera: Aphididae) in the neotropical region. Rev. Biol. Trop. 51,
279.

Prasad, S.M., Sarkar, D.P. 1989. Some ecological studies on Papaya ringspot virus in Ranchi. Indian J. Virol. 5, 118-122.

Purcifull, D.E., Edwardson, J.R., Hebert, E., Gonsalves, D., 1984. Description of Plan Viruses: Papaya Ringspot Virus. http://www.dpvweb.net/dpv/showdpv.php? dpvno $=292$.

Rezende, J.A.M., Martins, M.C., 2005. Doenças do mamoeiro (Carica papaya). In: Kimati, H., Amorim, L., Rezende, J.A.M., Bergamin Filho, A., Camargo, L.E.A (Eds.), Manual de fitopatologia: doenças das plantas cultivadas. Ed. Agronômica Ceres, São Paulo, Brasil, pp. 435-443.

Rezende, J.A.M., Müller, G.W., 1995. Mecanismos de proteção entre os vírus e controle de viroses de vegetais por premunização. Revisão Anu. Patol. Plantas 3 185-226.

Singh, V., Rao, G.P., Shukla, K., 2005. Response of commercially important papaya cultivars to papaya ringspot virus in eastern U.P. conditions. Indian Phytopathol. $58,212-216$.

Souza-Silva, C.R., Ilharco, F.A., 1995. Afídeos do Brasil e suas plantas hospedeiras (lista preliminar). Edufscar, São Carlos, Brasil.

Spadotti, D.M.A., Buriolla, J.E., Rezende, J.A.M., Souza, V.C., 2013. The wild type of Momordica charantia is not infected by potyviruses that cause disease in papaya and cucurbit crops. Trop. Plant Pathol. 38, 447-451.

Tennant, P.F., Fermin, G.A., Roye, M.E., 2007. Viruses infecting papaya (Carica papaya L.): ethiology, pathogenesis, and molecular biology. Plant Viruses 1, 178-188.

Tripathi, S., Suzuki, J., Ferreira, S., Gonsalves, D., 2008. Papaya ringspot virus-P: characteristics, pathogenicity, sequence variability and control. Mol. Plant Pathol. 9, 269-280.

Tropicos, 2013. Missouri Botanical Garden. http://www.tropicos.org.

Vegas, A., Cermeli, M., Trujillo, G., 1985. Áfidos con el vírus de la mancha anillada de la lechosa en Venezuela: presencia, transmisión y eficiencia. Agron. Trop. 35 25-31.

Ventura, J.A., Costa, H., Tatagiba, J.S., 2004. Papaya diseases and integrated control. In: Naqvi, S.A.M.H. (Ed.), Diseases of Fruits and Vegetables: Diagnosis and Management. Klumer Academic Publishers, London, pp. 201-268.

Videla, R.E.P., 1953. Las virosis de la lechosa (Carica papaya L.) en Venezuela. I. Transmisión del mosaico. Agron. Trop. 2, 241-251.

Wang, H.L., 1981. Aphid transmission of Papaya ringspot virus in Taiwan. Plant Prot. Bull. 23, 229-233. 